\title{
Fossil Fuel Rents: Who Initiates International Crises?
}

\author{
Journal Article
}

Author(s):

Bakaki, Zorzeta

Publication date:

2016-04-01

Permanent link:

https://doi.org/10.3929/ethz-b-000117158

Rights / license:

In Copyright - Non-Commercial Use Permitted

Originally published in:

Peace Economics, Peace Science and Public Policy 22(2), https://doi.org/10.1515/peps-2016-0001 


\title{
Zorzeta Bakaki* \\ Fossil Fuel Rents: Who Initiates International Crises?
}

DOI 10.1515/peps-2016-0001

Previously published online April 20, 2016

\begin{abstract}
Existing research suggests that both natural resource abundance and scarcity are likely to increase the risk of interstate and domestic conflict. Two crucial aspects, however, have largely been neglected in the existing literature: (1) the analysis of international crises (i.e. non-violent conflicts) and (2) the effects of different market conditions of energy resources. Especially a growing number of market participants can affect the strategic value of natural resources and, thus, the incentives for international crisis initiation. It is argued that different market structures make countries to adopt either aggressive or more peaceful behavior towards other states, and this is why I empirically then disaggregate fossil fuels along with the market that they belong to. This study examines 179 countries at the monadic level since 1980. The results suggest variation on the incentives of crisis initiation along the different fossil fuels, while I also correct for potential endogeneity issues.
\end{abstract}

Keywords: international crisis, natural resource, endogeneity, instrumental variable

\section{Introduction}

Often literature employs the term "petro-aggression" to show that major oil exporters are more likely to engage in crises when oil prices are high (Friedman 2009). In other words, oil rents reduce "the leader's risk of domestic punishment for foreign policy adventurism" (Colgan 2013, 161) and thus, provide incentives to engage in international crises.

Other literature suggests that the increasing globalization of energy markets (Goldthau and Witte 2009) and the increasing competition in certain segments of oil production (Hughes and Long 2015) has changed states' behavior in the international system. These changing market conditions often decrease the incentive

\footnotetext{
*Corresponding author: Zorzeta Bakaki, ETH Zürich, Center for Comparative and International Studies, Haldeneggsteig 4, 8092 Zürich, Switzerland, Phone: +41 446320264 , E-mail: zorzeta.bakaki@ir.gess.ethz.ch
} 
for foreign policy adventurism because consumers are able to substitute unreliable suppliers.

This study builds on the idea that market incentives matter (Månsson 2014) by systematically analyzing whether fossil fuel exporters ${ }^{1}$ tend to engage more often in international crises. I extend the framework developed by Colgan (2013) within the framework of "producer politics". I introduce a "rents-pacification" argument that suggests that fossil fuel exporters do not risk their fossil revenues in order to get engaged in a crisis.

I examine the opportunity costs associated with assertive behavior of exporters across three market structures: (1) monopoly, (2) oligopoly and (3) free market. Based on the rates of fossil fuel rents and the market competition, gas represents a stylized example for a monopoly (very few competitors if not only one competitor) (Gordon et al. 2003; Henderson and Pirani 2014; Saidu 2008), oil for an oligopoly (a few competitors) (Cologni and Manera 2014) and coal for a free market structure (many competitors) (Böhringer and Rutherford 2002). Under conditions of monopoly, I expect the domination of a "petro-aggression" mechanism, because states have relatively low opportunity costs of initiating a crisis. Under conditions of oligopoly, it dominates a "rents-pacification" mechanism, as exporters have to face the possibility of consumers switching to other suppliers. Finally, under free market conditions, I expect that the opportunity costs of initiating a crisis are low since free market products are easily accessible and inexpensive.

There is little systematic research and inclusive empirical findings, linking fossil fuels and international crises onset (Bove et al. 2015; Koubi et al. 2014; Sovacool 2014). Apart from making a general contribution to this strand of research, this study: (1) systematically tests the probability of states' crises initiation, (2) disaggregates fossil fuels according to different market structures and introduces the "rents-pacification" argument, and (3) solves the potential endogeneity bias, by proposing an instrumental variable. ${ }^{2}$

Energy fossil fuels' rents of different economic markets have an impact on states' choice of initiating a crisis. The type of the market that each product belongs to determines the direction of the outcome. That is, exporters of monopolistic and free market products appear with an aggressive policy behavior whilst exporters of other markets (oligopoly) consider potential loses of their revenues when triggering a crisis.

1 For simplicity reasons I use the word exporters throughout the text but this also refers to states with domestic profits from fossil fuel rents.

2 Instrumental variable approach to account for endogeneity was also utilized by Ramsay (2011) and Brunnschweiler and Bulte (2009). 


\section{Energy resources and paths to international crisis}

A state initiates a crisis only if it expects more gains through crises rather than through other means (Bueno de Mesquita 1980; Powell 2006; Reiter 2003; Wagner 2000). The key to understanding the incentives of the energy rents countries is to think about the opportunity costs associated with different paths of crisis initiation. Along the same lines, trade might increase the opportunity costs of conflicts and thus lead to more peaceful relations (Hegre et al. 2010; Oneal and Russett 1999). Nonetheless, under certain market conditions, (e.g. trade asymmetries) trade can also fuel conflicts (Barbieri 1996; Garfinkel et al. 2008).

To further our understanding of potential opportunity costs that fossil-fuel countries have to face when initiating an international crisis, I relate the opportunity costs to different market structures. I classify the market conditions by the number of competitors in the market: (1) monopoly (one dominant exporter), (2) oligopoly (a few dominant exporters) and (3) free market (many exporters). I base my theoretical argument on the presumption that there are always many consumers in the market, and I develop the following three scenarios.

In an oligopolistic market (oil rents) the major exporter is uncertain about the opportunity costs of initiating a crisis against another state, as the clients might still have a few alternative oil exporters. In this scenario the consumer states can interpret initiation of an international crisis as a threat to their supplies and can decide to switch to another exporter. If a major consumer or many consumers switch to another supplier, it means a significant loss of revenues for the exporter. Consequently, under these market conditions the major exporters might prefer to keep political stability in order to protect their revenues. Thus, in this case instead of petro-aggression, I expect the dominance of a rents-pacification behavior.

In a monopolistic market (gas rents) a major exporter has relatively low opportunity costs of initiating a crisis against another state, as there is not alternative exporter in the market. The exporter state can assume that other consumers do not have a credible alternative and the prospect of switching to another exporter and thus, the revenues will not be affected by the country's aggressive foreign policy behavior. Additionally, given the strategic value of energy (Yergin 2006), the dominance in the energy market might be easily transposed into political or military power preponderance, thus creating more incentives to initiate an international crisis.

In a free market (coal rents) a major exporter takes smaller share of the market and thus generally smaller revenues as compared to monopolistic or 
oligopolistic markets. ${ }^{3}$ Smaller revenues are then associated with lower opportunity costs when initiating a crisis. In a free market where many states cover their needs for coal by their own domestic production, losing a few consumers who do not approve of a potential aggressive foreign policy behavior might not hurt economically the exporter state. Hence, under free market conditions exporters will be less concerned about their reputational damage among the consumers, and will, therefore, initiate more international crises.

Based on the aforementioned considerations I propose the following hypotheses:

H1: Countries with high oil rents do not initiate international crises (oligopolistic market conditions).

H2: Countries with high gas rents initiate international crises (monopolistic market conditions).

H3: Countries with high coal rents initiate international crises (free market conditions).

\section{Methodological approach}

For this analysis I employ the actor level data of the International Crisis Behavior (ICB) Project for 179 countries from 1980 to 2006. A recent crisis in the dataset is the regime change in Iraq, which was triggered by the US in 2002 with the involvement of the United Kingdom (UK). The year 2002 is thus coded as a crisis year for Iraq, USA and UK. Meanwhile, 2003 is not a crisis year in the dataset as the crisis was escalated to war. Although a dyadic level of analysis would account for the relations of pairs of states in the market, the ultimate goal of this study is to examine whether there is a difference across the type and the quantity of the energy goods that countries export and their incentives to initiate an international crisis.

\subsection{Crisis initiation}

Existing literature indicates that the relation between interstate crises and energy natural resources remains rarely analyzed (Koubi et al. 2012). Due to the decrease

3 Given that many countries produce coal themselves, the export rates of coal are rather low and therefore the total revenues are also smaller. 
of international armed conflict (Gleditsch and Pickering 2014), I examine the impact of energy resources in international crises and move beyond an examination of the Militarized Interstate Dispute (MID) data (Ghosn et al. 2004). The dependent variable, crisis initiation, indicates the trigger of a crisis by a state actor in a specific year. ${ }^{4}$ It is a binary variable that is coded 1 for crisis initiation ( 0 otherwise). I use the monadic version of the International Crisis Behavior dataset (ICB) (Brecher and Wilkenfeld 2010).

\subsection{Fossil fuel rents}

Smith (forthcoming) proposes a measurement of "rent leverage" computed by dividing fuel income per capita with the purchasing power parity (PPP)-corrected GDP per capita. In other words, the measure employed by Smith is highly linked to the average citizen's livelihood. This, in turn, can impact on domestic political stability. While this measure might indeed be appropriate for the analysis of domestic mechanisms that lead to political instability and domestic conflict, for the purposes of this study, I opt for a simple measure that only refers to the revenues made by fossil fuels. That is, I measure fossil fuel rents as the percentage of GDP that is in GDP 2005 prices. Ultimately, this measure focuses on state capacity per se that could potentially have some impact on international crises. The theoretical framework suggests that certain market conditions have a restrictive effect on aggressive foreign policy behavior, regardless whether rents are used to boost patronage or not. Thus, I employ the World Bank's indicators for oil, gas and coal, which are estimated through the difference between the values of production at world prices and total costs of production (The World Bank Indicators 2015).

\subsection{Instrumental variable}

Endogeneity is a major methodological problem in the study of the relationship between natural resources and crises (Brunnschweiler and Bulte 2009; Koubi et al. 2012; Lujala 2009; Mitchell and Thies 2012; Ross 2006). Economic and political factors that are meant to explain the dependent variable of interest (crisis initiation) are likely to affect the main explanatory variables (fossil fuels) as well. In order to address this endogeneity problem, this study employs an instrumental model approach.

4 Refer to the Appendix for a list of the countries included in the sample indicating whether they initiated a crisis between 1980 and 2006. 
A valid instrument is a variable that is correlated with the key independent variable, but at the same time it should be uncorrelated with the error term. In turn, this can resolve the problems that measurement error, omitted variable bias, and simultaneous causation create - "endogeneity bias” (Ramsay 2011). That is, an instrumental variable replaces the problematic independent variable with a substitution variable that is uncontaminated by error or unobserved factors that affect the outcome. The literature offers a series of instruments aiming to solve potential endogeneity bias in the study of natural resources. ${ }^{5}$

For the purposes of this analysis, I employ the terrain quality as an instrument. Two major conditions have to be satisfied for an instrument to provide consistent parameter estimates: (1) the instrument has to be exogenous to international crisis initiation (dependent variable) and (2) it has to be related to changes in fossil fuel rents (core explanatory items).

Arguing that terrain quality does not affect the probability of crisis initiation satisfies the first condition. Civil war research indicates that terrain quality is a factor influencing intrastate conflict, because it allows rebels to hide from the stronger government forces, thus addressing the power asymmetry between state and non-state actors (Buhaug and Gates 2002; Fearon and Laitin 2003; Hegre and Sambanis 2006). That said, there is no obvious argument for why terrain quality should affect the likelihood of international crisis initiation. To be clear: while there are arguments linking domestic conflict, and its underlying processes, with the outbreak of interstate disputes (Salehyan 2008), none of the arguments in the literature refers to terrain quality. Hence, I can consider the variable on terrain quality as an exogenous factor and, in fact, an unrelated determinant of international crisis.

Regarding the second condition, the terrain quality must be related to the fossil fuels (oil, gas and coal). To this end, I consider a basic parameter of fossil fuel rents, i.e. the method of transportation as a link between our instrument and fossil fuel rents. I expect that the less difficult the transportation of a product, the higher the rents that it may generate. Oil, gas, and coal are mostly transported using trucks, trains, and pipelines. Transportation is fairly easy and cheap when a country's terrain is approachable. Pipelines, for instance, are considered the

5 For example, Ramsay (2011) examines the relationship between resource income and political freedom employing the occurrence of natural disasters as an instrument. Along the same lines, Tsui (2011) examines the long-term effect of discovering oil, and uses oil discoveries as an instrument for oil wealth. Brunnschweiler and Bulte (2009) explore the nature of the causal link between resources and the onset of war, using a set of exogenous instruments such as geographical variables (i.e. distance to the nearest coast), the average openness to trade and government system. 
safest method of fuels' transportation. Pipelines are located away from the woods and forested areas. However, rough or mountainous terrain might constitute a problem for the construction of pipelines; it might be either not feasible to construct a pipeline at all or too expensive. For the aforementioned reasons, terrain quality is likely to be strongly associated with fossil fuel rents.

Table 1 summarizes the measurement and sources for all variables included in the analysis and Table 2 illustrates descriptive statistics of all variables.

\section{Empirical analysis}

I first present probit models (Tables 3-5) that examine a direct relationship between crisis initiation and fossil fuels. I, however, expect that the results obtained through probit estimations be biased because fossil fuel exports are endogenous to international crises (Brunnschweiler and Bulte 2009; Koubi et al. 2012; Lujala 2009; Ross 2006). To obtain robust results I apply an instrumental variable approach (Brunnschweiler and Bulte 2009; Ramsay 2011) and compute probit models with endogenous regressors (ivprobit). Thus, I proceed with the analysis of the instrumental models (Tables 3-5) and I present second stage results for ivprobit. Considering the structure of the instrumental model, I employ a test that examines the magnitude of the endogenous coefficients' effect (oil, gas and coal rents). Hence, I implement a robust postestimation test for instrumental models provided by Mikusheva and Poi (2006); see also Finlay and Magnusson 2009). This robust-instrumental variable test ("rivtest") examines whether the coefficient of an endogenous variable (oil, gas and coal rents) is different from 0 (null hypothesis). For the instrumental-variable probit, the rivtest calculates the minimum distance version of the Anderson-Rubin (AR) test statistic (a joint test of the structural parameter) and it presents the Wald test. A statistically significant value for both measures suggests that the coefficient of the endogenous variable is different from 0 , which provides strong evidence in turn that the instrument is suitable. Inconsistent results across the two measures (AR and Wald) may but do not have necessarily - point to weak instrument, as the Wald test can be unsuitable for weak instruments (not the AR test, though). The AR test is a more conservative statistic.

When examining the impact of oil and coal rents on crisis initiation, both measures (AR and Wald) are significant. This indicates that the results presented in the instrumental models (Tables 3 and 5) are robust. Coming to the impact of gas on crisis initiation, the AR and Wald tests are not consistently significant, which may affect - but not necessarily - the robustness of the results of the IV 


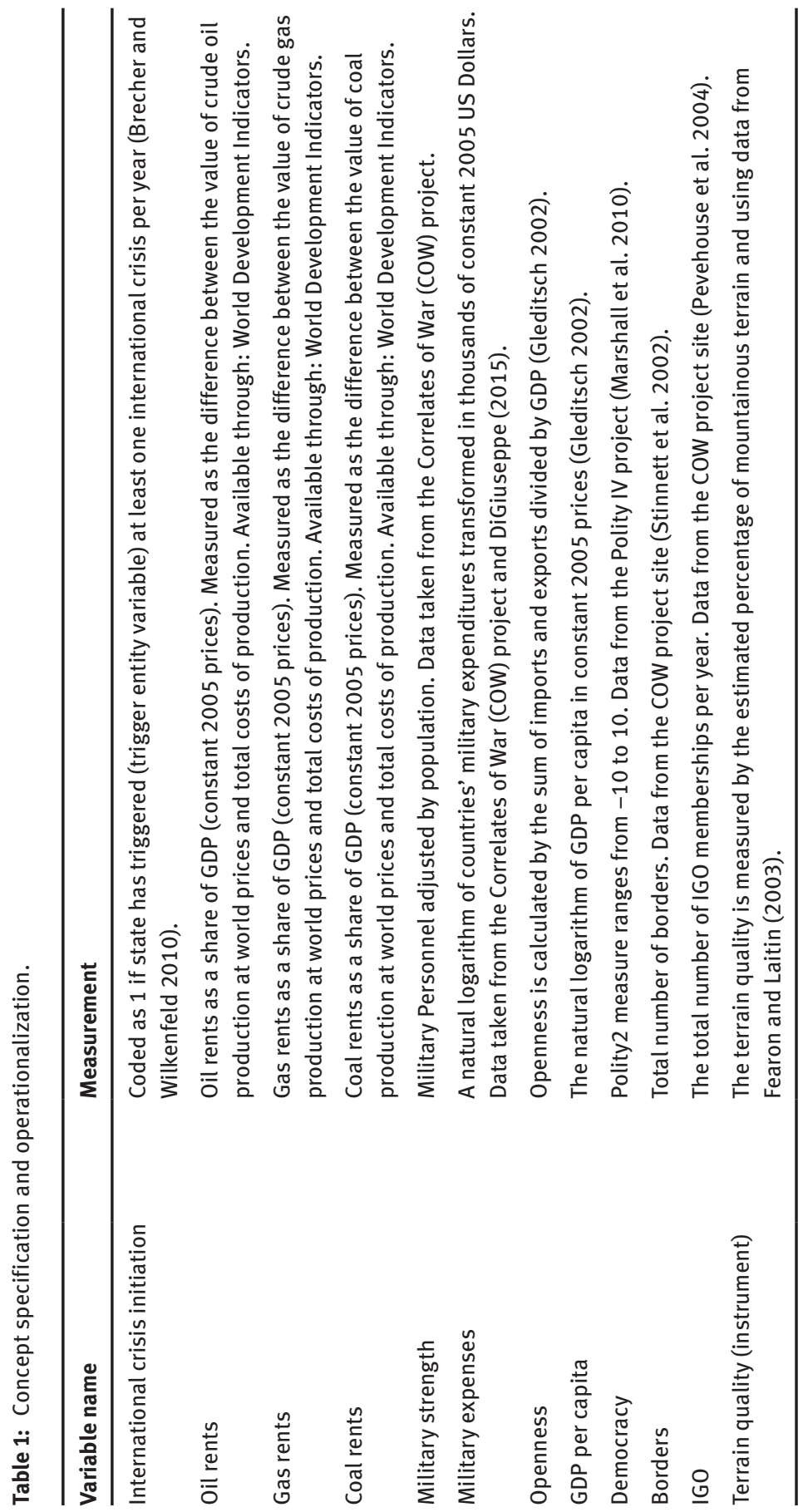


Table 2: Descriptive statistics.

\begin{tabular}{lrrrrr}
\hline Variable & Obs. & Mean & Std. dev. & Min & Max \\
\hline International crisis initiation & 4698 & 0.04 & 0.19 & 0 & 1 \\
Oil rents (lag) & 3954 & 4.30 & 10.67 & 0.00 & 78.93 \\
Gas rents (lag) & 4275 & 0.73 & 3.26 & 0.00 & 64.90 \\
Coal rents (lag) $_{\text {GDP }_{\text {In }} \text { (lag) }}$ & 4327 & 0.05 & 0.30 & 0.00 & 6.85 \\
Democracy (lag) $_{\text {Borders }}^{4280}$ & 8.35 & 1.18 & 4.90 & 11.52 \\
Military Strength (lag) $_{\text {Military expenses }}$ (lag) & 3643 & 1.50 & 7.34 & -10 & 10 \\
Openness (lag) $_{\text {IGO (lag) }}^{4324}$ & 5.81 & 3.40 & 0 & 29 \\
Quality of terrain (instrumental variable) & 3923 & 3.06 & 2.49 & 0 & 0.08 \\
\hline
\end{tabular}

model presented in Table 4. To provide further evidence that the terrain quality indicator is indeed an exogenous item, I also provide a reduced form model (Table 6) that examines directly the relationship between the dependent variable of interest (crisis initiation) and the instrumental variable (terrain quality). The results show that there is no statistically significant relationship between the two measures. That is, I am confident that in the IV-probit regression, I can employ the terrain quality for oil, gas and coal rents as an instrument in the selection equation.

Model 2 in Table 3 shows that countries with oil rents are statistically significant associated with crisis initiation. The probability of crisis initiation decreases with oil rents. I also calculated substantive effects in the form of predicted probabilities. When examining these, the probability of crisis initiation is around 15\% for the minimum value of oil rents; conversely, the risk of triggering a crisis drops by 5\%-points, when moving to the maximum of the oil rents item. These findings are in line with the theoretical argument above: states with insignificant revenues might trigger a crisis. The underlying assumption is that countries with insignificant revenues might trigger a crisis in order to challenge the stability of the energy market.

With regard to gas rents (Table 4), I find that states having a monopoly are more likely to initiate a crisis, knowing that there is unlikely to be much damage to their fuel revenues (Model 2). Indeed, the substantive effect of gas rents emphasizes that the maximum value of gas rents is associated with a conflict initiation risk of $37 \%$.

Rents from a free market product, such as coal (Table 5), increase the probability of crisis initiation, as the damage of the revenues would be smaller (Model 
Table 3: Crisis initiation: effects of oil rents (oligopolistic market) (1980-2006).

\begin{tabular}{|c|c|c|}
\hline & $\begin{array}{r}\text { (Model 1) } \\
\text { Probit }\end{array}$ & $\begin{array}{r}\text { (Model 2) } \\
\text { IV Probit }\end{array}$ \\
\hline Oil rents (lag) & $\begin{array}{r}0.00 \\
(0.00)\end{array}$ & $\begin{array}{r}-0.07^{\star \star} \\
(0.02)\end{array}$ \\
\hline $\mathrm{GDP}_{\text {In }}$ (lag) & $\begin{array}{r}-0.14^{\star \star} \\
(0.06)\end{array}$ & $\begin{array}{r}0.05 \\
(0.11)\end{array}$ \\
\hline Democracy (lag) & $\begin{array}{l}0.02^{\star} \\
(0.00)\end{array}$ & $\begin{array}{l}-0.03 \\
(0.02)\end{array}$ \\
\hline Borders & $\begin{array}{r}0.01 \\
(0.01)\end{array}$ & $\begin{array}{l}0.05^{*} \\
(0.02)\end{array}$ \\
\hline Military strength (lag) & $\begin{array}{r}16.39^{* *} \\
(6.48)\end{array}$ & $\begin{array}{l}10.11 \\
(6.60)\end{array}$ \\
\hline Military expenses $_{\text {In }}$ (lag) & $\begin{array}{r}0.08^{\star \star} \\
(0.03)\end{array}$ & $\begin{array}{r}0.14^{\star \star} \\
(0.02)\end{array}$ \\
\hline Openness (lag) & $\begin{array}{r}0.01 \\
(0.00)\end{array}$ & $\begin{array}{l}-0.01 \\
(0.00)\end{array}$ \\
\hline IGO (lag) & $\begin{array}{l}-0.00 \\
(0.00)\end{array}$ & $\begin{array}{r}-0.01^{\star *} \\
(0.00)\end{array}$ \\
\hline $\mathrm{t}$ & $\begin{array}{r}-0.12^{\star} \\
(0.05)\end{array}$ & $\begin{array}{r}-0.10^{*} \\
(0.04)\end{array}$ \\
\hline$t^{2}$ & $\begin{array}{r}0.00 \\
(0.00)\end{array}$ & $\begin{array}{r}0.00 \\
(0.00)\end{array}$ \\
\hline$t^{3}$ & $\begin{array}{l}-0.00 \\
(0.00)\end{array}$ & $\begin{array}{l}-0.00 \\
(0.00)\end{array}$ \\
\hline Constant & $\begin{array}{r}-1.18^{\star *} \\
(0.44)\end{array}$ & $\begin{array}{r}-2.77^{\star \star} \\
(0.47)\end{array}$ \\
\hline $\mathrm{N}$ & 3036 & 2783 \\
\hline Pseudo $\mathrm{R}^{2}$ & 0.16 & \\
\hline Wald $\chi^{2}$ & $150.68^{\star *}$ & $295.27^{\star *}$ \\
\hline
\end{tabular}

All explanatory variables except the borders are lagged by 1 year.

Standard errors in parentheses ${ }^{* *} \mathrm{p}<0.01,{ }^{*} \mathrm{p}<0.05$.

2). The substantive effects indicate that states with high coal revenues (maximum value of that variable) have a probability of about $90 \%$ to initiate a crisis (holding all other variables constant at their means), while states characterized by the lowest value of coal revenues have risk of triggering a crisis of around $75 \%$. 
Table 4: Crisis initiation: effects of gas rents (monopolistic market) (1980-2006).

\begin{tabular}{|c|c|c|}
\hline & $\begin{array}{r}\text { (Model 1) } \\
\text { Probit }\end{array}$ & $\begin{array}{r}\text { (Model 2) } \\
\text { IV Probit }\end{array}$ \\
\hline Gas rents (lag) & $\begin{array}{l}-0.05 \\
(0.03)\end{array}$ & $\begin{array}{r}0.25^{\star \star} \\
(0.03)\end{array}$ \\
\hline $\mathrm{GDP}_{\text {In }}$ (lag) & $\begin{array}{r}-0.16^{\star \star} \\
(0.06)\end{array}$ & $\begin{array}{r}-0.10^{\star \star *} \\
(0.02)\end{array}$ \\
\hline Democracy (lag) & $\begin{array}{l}0.02^{\star} \\
(0.00)\end{array}$ & $\begin{array}{r}0.03^{* *} \\
(0.00)\end{array}$ \\
\hline Borders & $\begin{array}{r}0.02 \\
(0.02)\end{array}$ & $\begin{array}{r}-0.03^{\star *} \\
(0.00)\end{array}$ \\
\hline Military strength (lag) & $\begin{array}{r}17.27^{\star \star} \\
(6.58)\end{array}$ & $\begin{array}{r}21.51^{\star \star} \\
(4.73)\end{array}$ \\
\hline Military expenses $_{\text {In }}$ (lag) & $\begin{array}{r}0.08^{\star *} \\
(0.03)\end{array}$ & $\begin{array}{l}-0.03 \\
(0.04)\end{array}$ \\
\hline Openness (lag) & $\begin{array}{r}0.01 \\
(0.01)\end{array}$ & $\begin{array}{r}-0.01 \text { ** } \\
(0.01)\end{array}$ \\
\hline IGO (lag) & $\begin{array}{l}-0.00 \\
(0.00)\end{array}$ & $\begin{array}{r}0.01^{* *} \\
(0.01)\end{array}$ \\
\hline $\mathrm{t}$ & $\begin{array}{r}-0.11^{*} \\
(0.07)\end{array}$ & $\begin{array}{l}-0.05 \\
(0.04)\end{array}$ \\
\hline$t^{2}$ & $\begin{array}{r}0.00 \\
(0.00)\end{array}$ & $\begin{array}{r}0.00 \\
(0.00)\end{array}$ \\
\hline$t^{3}$ & $\begin{array}{l}-0.00 \\
(0.00)\end{array}$ & $\begin{array}{l}-0.00 \\
(0.00)\end{array}$ \\
\hline Constant & $\begin{array}{r}1.18^{\star \star} \\
(0.45)\end{array}$ & $\begin{array}{l}1.04^{*} \\
(0.50)\end{array}$ \\
\hline $\mathrm{N}$ & 3014 & 2776 \\
\hline Pseudo $\mathrm{R}^{2}$ & 0.16 & \\
\hline Wald $\chi^{2}$ & $144.91^{\star \star}$ & $648.19^{\star \star}$ \\
\hline
\end{tabular}

All explanatory variables except the borders are lagged by 1 year.

Standard errors in parentheses ${ }^{* \star} p<0.01,{ }^{*} p<0.05$.

Coming to the control variables, the results show that GDP per capita affects the risk of crisis initiation differently across markets. That is, wealthier countries are less likely to initiate a crisis in the model that focuses on gas. The results suggest that the impact of GDP per capita might differ as soon as we consider the impact of oil and coal rents that, however, mirrors much of the earlier research. 
Table 5: Crisis initiation: effects of coal rents (competitive market) (1980-2006).

\begin{tabular}{|c|c|c|}
\hline & $\begin{array}{r}\text { (Model 1) } \\
\text { Probit }\end{array}$ & $\begin{array}{r}\text { (Model 2) } \\
\text { IV Probit }\end{array}$ \\
\hline Coal rents (lag) & $\begin{array}{r}0.18 \\
(0.10)\end{array}$ & $\begin{array}{r}3.07^{\star \star} \\
(0.16)\end{array}$ \\
\hline $\mathrm{GDP}_{\text {In }}$ (lag) & $\begin{array}{r}-0.16^{* \star} \\
(0.06)\end{array}$ & $\begin{array}{l}-0.05 \\
(0.06)\end{array}$ \\
\hline Democracy (lag) & $\begin{array}{l}0.02^{\star} \\
(0.00)\end{array}$ & $\begin{array}{l}-0.00 \\
(0.00)\end{array}$ \\
\hline Borders & $\begin{array}{r}0.01 \\
(0.01)\end{array}$ & $\begin{array}{r}-0.03^{\star \star} \\
(0.00)\end{array}$ \\
\hline Military strength (lag) & $\begin{array}{r}20.09^{\star \star} \\
(6.56)\end{array}$ & $\begin{array}{r}21.67^{\star \star} \\
(5.04)\end{array}$ \\
\hline Military expenses $_{\text {In }}$ (lag) & $\begin{array}{l}0.06^{*} \\
(0.03)\end{array}$ & $\begin{array}{l}-0.07 \\
(0.04)\end{array}$ \\
\hline Openness & $\begin{array}{r}0.00 \\
(0.00)\end{array}$ & $\begin{array}{r}-0.01^{\star *} \\
(0.00)\end{array}$ \\
\hline IGO (lag) & $\begin{array}{l}-0.01 \\
(0.00)\end{array}$ & $\begin{array}{r}0.02^{\star *} \\
(0.00)\end{array}$ \\
\hline $\mathrm{t}$ & $\begin{array}{r}-0.11^{\star} \\
(0.05)\end{array}$ & $\begin{array}{r}0.01 \\
(0.04)\end{array}$ \\
\hline$t^{2}$ & $\begin{array}{r}0.00 \\
(0.00)\end{array}$ & $\begin{array}{l}-0.00 \\
(0.00)\end{array}$ \\
\hline$t^{3}$ & $\begin{array}{l}-0.00 \\
(0.00)\end{array}$ & $\begin{array}{r}0.00 \\
(0.00)\end{array}$ \\
\hline Constant & $\begin{array}{r}-1.02^{\star \star} \\
(0.44)\end{array}$ & $\begin{array}{l}-0.17 \\
(0.36)\end{array}$ \\
\hline $\mathrm{N}$ & 3021 & 2783 \\
\hline Pseudo $\mathrm{R}^{2}$ & 0.16 & \\
\hline Wald $\chi^{2}$ & $145.11^{\star \star}$ & $3356.89 * *$ \\
\hline
\end{tabular}

All explanatory variables except the borders are lagged by 1 year.

Standard errors in parentheses ${ }^{* \star} \mathrm{p}<0.01,{ }^{\star} \mathrm{p}<0.05$.

Moreover, countries' military capabilities and military expenses positively affect crisis initiation almost consistently across the models. For instance, the average elasticity of military capabilities across all models is 0.14 . The average elasticity of military expenses across all models is 0.70 . Similarly, more memberships in international organizations are associated with a higher likelihood of 
Table 6: Crisis initiation and terrain quality (reduced form model) (1980-2006).

\begin{tabular}{|c|c|}
\hline & $\begin{array}{r}\text { (Model 1) } \\
\text { Probit }\end{array}$ \\
\hline Quality of the terrain & $\begin{array}{r}0.07 \\
(0.04)\end{array}$ \\
\hline $\mathrm{GDP}_{\text {In }}$ (lag) & $\begin{array}{r}-0.20^{\star \star} \\
(0.06)\end{array}$ \\
\hline Democracy (lag) & $\begin{array}{l}0.02^{*} \\
(0.00)\end{array}$ \\
\hline Borders & $\begin{array}{r}0.00 \\
(0.00)\end{array}$ \\
\hline Military strength (lag) & $\begin{array}{r}17.84^{\star \star} \\
(6.40)\end{array}$ \\
\hline Military expenses ${ }_{\text {In }}$ (lag) & $\begin{array}{r}0.12^{\star \star} \\
(0.03)\end{array}$ \\
\hline Openness (lag) & $\begin{array}{r}0.00 \\
(0.00)\end{array}$ \\
\hline IGO (lag) & $\begin{array}{l}-0.00 \\
(0.00)\end{array}$ \\
\hline $\mathrm{t}$ & $\begin{array}{r}-0.13^{* *} \\
(0.05)\end{array}$ \\
\hline$t^{2}$ & $\begin{array}{r}0.00 \\
(0.00)\end{array}$ \\
\hline$t^{3}$ & $\begin{array}{l}-0.00 \\
(0.00)\end{array}$ \\
\hline Constant & $\begin{array}{r}-1.53^{\star \star} \\
(0.46)\end{array}$ \\
\hline $\mathrm{N}$ & 2872 \\
\hline Pseudo $\mathrm{R}^{2}$ & 0.18 \\
\hline Wald $\chi^{2}$ & $169.18^{\star \star}$ \\
\hline
\end{tabular}

All explanatory variables except the quality of terrain and borders are lagged by 1 year. Standard errors in parentheses ${ }^{* *} \mathrm{p}<0.01,{ }^{*} \mathrm{p}<0.05$.

crisis initiation (in the models on gas and coal rents), which mirrors the underlying rationale of states being more involved in international affairs to be involved in more low-intensity conflict. That said, when examining the effect of oil rents, states with fewer memberships are more likely to initiate crisis.

Furthermore, I find that openness is a significantly positive indicator of crisis initiation in the model on coal while it has significantly negative impact on crisis initiation in the model on gas rents. Nevertheless, openness is not statistically significant to crisis initiation in the model on oil rents. Shared borders are usually associated with a better opportunity for crisis (oil rents), and I find some evidence for this albeit not consistently across the different estimations. 
The findings, finally, highlight that democracies seem to be prone to crisis initiation (gas rents). The democracy effect is statistically insignificant in the models on oil and coal rents.

The overall results illustrate what are the actors that are likely to trigger a crisis based on the fossil fuel product they produce and thus make income. In an attempt to examine the different market structures of fossil fuels with regards to crisis initiation, the results indicate that free markets and monopolies have a higher probability of triggering a crisis due to the low associated opportunity costs with energy revenues. In essence, these markets are placed at the extremes of the market structure. A monopoly (gas) faces little competition issues, if not at all (see also Gordon et al. 2003; Henderson and Pirani 2014; Saidu 2008). Strictly speaking, a monopoly consists of only one producer. However, the general development of fossil fuel production allows few countries to produce small quantities of gas as well (e.g. Italy, Denmark) (Glachant et al. 2013). And this is precisely the reason why gas can be referred to a "clumsy" monopoly. This is similar to the case of oil that few decades ago belonged to a "clumsy" monopoly, before it switched to an oligopoly market (Adelman 2004). Yet, when only one state is the major exporter of a fossil fuel (i.e. gas), we still refer to a monopoly. Although, a free market (coal) is usually very competitive, the reality that there are many producers makes the product less desirable and as a result of a lower importance for a country's revenues. On the contrary, a country of an oligopolistic product (oil) deals with a lot of uncertainty due to the amount of producers and the excessive need for the product. Therefore, the revenues from an oligopolistic market product are not stable and often very subtle to the market's fluctuations. This makes countries that rely on oil revenues more careful and rather risk averse towards their relations with other states.

\section{Conclusion}

Previous studies have considered different types of resources as influential to conflict (i.e. oil and diamonds) (Ross 2006). With a few exceptions (Goenner 2010) the different levels of competition across the major energy markets have not been explicitly addressed by the existing literature. For this reason I have disaggregated the energy resources according to the level of competition in the markets, and examined the association with crisis initiation.

The results indicate that countries with oil rents acknowledge the instability of the oligopolistic market that oil belongs to, and they choose a pacifier's behavior in their relations with other states. Countries with rents from monopolistic and free markets products -although very different structures- behave similarly with a positive relationship to crisis initiation. The features of the markets allow 
the actors to adopt aggressive behavior, given that their energy revenues are not affected, either because there is no competition (gas) or because the very high levels of competition (coal) generate small benefits. The major assumption behind this link is that actors before initiating a crisis calculate the potential damage. In these markets the damage of the fuels revenues is ultimately small because there are no many alternative gas exporters in the market and because there is very little need for coal imports. Therefore, "the resource backed aggression" (Colgan 2010) is reversed to "market restricted behavior" and thus, pacifier's behavior for fossil-fuel states of an oligopolistic market (i.e. oil).

A prominent example of a major monopoly as a gas supplier is Russia. That said, the Russian market share as the dominant gas supplier has been declining since 1997 and overall the market has been exhibiting an increasing competition. Therefore, the expectation is to see a decline in crisis initiation also by the major gas exporters in the future due to the change of the market structure.

In general, the study of states' relations over fossil fuels is related to the literature on the pacifying effects of trade between states (e.g. Polachek et al. 1999; Reuveny and Kang, 1998). For example, research generally shows that trade ties between states improve their bilateral relations (Barbieri 1996; Oneal and Russett 1999), although more disaggregated work (e.g. Dorussen 2006) emphasizes that the composition of trade flows (i.e. "what you trade") ultimately influences whether we see a pacifying or conflictive effect. Specifically, these latter studies find that there is variation across the types of commodities as they are "not uniform in their characteristics and can vary significantly in terms of their substitutability” (Goenner 2010, 550).

The present study examined the impact of oil rents on crisis initiation; yet, it is still worth examining whether governments also consider anticipated fossil fuel rents before initiating a crisis. That is, such a research question can be examined with prediction and forecasting techniques. In addition, while natural energy resources remain an important factor of states' behavior and relations, renewable energy resources might change the scenarios by increasing market competition and therefore, the interests of major exporters and consumers, respectively.

Acknowledgments: Particular thanks go to Elina Brutschin, the anonymous reviewer and the Editor for their useful insights and suggestions.

\section{References}

Adelman, M.A., (2004), The Real Oil Problem, Regulation, vol. 27, p. 16. Available at: http://heinonline.org/HOL/Page?handle=hein.journalsrcatorbg27\&div=8\&g_ sent $=1 \&$ collection $=$ journals. 
Barbieri, K., (1996), Economic Interdependence: A Path to Peace or a Source of Interstate Conflict?, Journal of Peace Research, vol. 33, no. 1, pp. 29-49.

Böhringer, C., Rutherford, T.F., (2002), Carbon Abatement and International Spillovers, Environmental and Resource Economics, vol. 22, no. 3, pp. 391-417.

Bove, V., Gleditsch, K.S., Sekeris, P.G., (2015), Oil above Water Economic Interdependence and Third-party Intervention, Journal of Conflict Resolution. Doi: 10.1177/0022002714567952.

Brecher, M., Wilkenfeld, J., (2010), International Crisis Behavior Data (ICB) Version 10. Available at: www.sites.duke.edu/icbdata/ (accessed on March 2016).

Brunnschweiler, C.N., Bulte, E.H., (2009), Natural Resources and Violent Conflict: Resource Abundance, Dependence, and the Onset of Civil Wars, Oxford Economic Papers, vol. 61, no. 4, pp. 651-674.

Bueno de Mesquita, B., (1980), An Expected Utility Theory of International Conflict, The American Political Science Review, vol. 74, no. 4, pp. 917-931.

Buhaug, H., Gates, S., (2002), The Geography of Civil War, Journal of Peace Research, vol. 39, no. 4, pp. 417-433.

Colgan, J.D., (2010), Oil and Revolutionary Governments: Fuel for International Conflict, International Organization, vol. 64, no. 04, pp. 661-694.

Colgan, J.D., (2013), Fueling the Fire: Pathways from Oil to War, International Security, vol. 38, no. 2, pp. 147-180.

Cologni, A., Manera, M., (2014), On the Economic Determinants of Oil Production: Theoretical Analysis and Empirical Evidence for Small Exporting Countries, Energy Economics, vol. 44, pp. 68-79.

DiGiuseppe, M., (2015), Guns, Butter and Debt: Sovereign Creditworthiness and Military Spending, Journal of Peace Research, vol. 52, no. 5, pp. 680-693.

Dorussen, H., (2006), Heterogeneous Trade Interests and Conflict What You Trade Matters, Journal of Conflict Resolution, vol. 50, no. 1, pp. 87-107.

Fearon, J., Laitin, D., (2003), Ethnicity, Insurgency and Civil War, American Political Science Review, vol. 97, no. 1, pp. 75-90.

Finlay, K., Magnusson, L.M., (2009), Implementing Weak-instrument Robust Tests for a General Class of Instrumental-variables Models, Stata Journal, vol. 9, no. 3, p. 398.

Friedman, T.L., (2009), The First Law of Petropolitics. Available at: www.foreignpolicy. com/2009/10/16/the-first-law-of-petropolitics/ (accessed on March 2016).

Garfinkel, M.R., Skaperdas, S., Syropoulos, C., (2008), Globalization and Domestic Conflict, Journal of International Economics, vol. 76, no. 2, pp. 296-308.

Glachant, J.M., Hallac, M., Vazquez, M., (2013), Building Competitive Gas Markets in the EU, Cheltenham, Uk-Northampton, MA, USA: Edward Elgar Publishing.

Gleditsch, K.S., (2002), Expanded Trade and GDP Data, Journal of Conflict Resolution, vol. 46, no. 5 , pp. $712-724$.

Gleditsch, K.S., Pickering, S., (2014), Wars are Becoming Less Frequent: A Response to Harrison and Wolf, The Economic History Review, vol. 67, no. 1, pp. 214-230.

Goenner, C.F., (2010), From Toys to Warships: Interdependence and the Effects of Disaggregated Trade on Militarized Disputes, Journal of Peace Research, vol. 47, no. 5, pp. 547-559.

Goldthau, A., Witte, J.M., (2009), Back to the Future or Forward to the Past? Strengthening Markets and Rules for Effective Global Energy Governance, International Affairs, vol. 85, no. 2, pp. 373-390.

Ghosn, F., Palmer, G., Bremer, S.A., (2004), The MID3 Data Set, 1993-2001: Procedures, Coding Rules, and Description, Conflict Management and Peace Science, vol. 21, no. 2, pp. 133-154. 
Gordon, D.V., Gunsch, K., and Pawluk, C.V., (2003), A Natural Monopoly in Natural Gas Transmission, Energy Economics, vol. 25, no. 5, pp. 473-485.

Henderson, J., Pirani, S., (2014), The Russian Gas Matrix: How Markets are Driving Change, Oxford, UK: Oxford University Press.

Hegre, H., Oneal, J.R., Russett, B., (2010), Trade Does Promote Peace: New Simultaneous Estimates of the Reciprocal Effects of Trade and Conflict, Journal of Peace Research, vol. 47, no. 6, pp. 763-774.

Hegre, H., Sambanis, N., (2006), Sensitivity Analysis of Empirical Results on Civil War Onset, Journal of conflict resolution, vol. 50, no. 4, pp. 508-535.

Hughes, L., Long, A., (2015), Is There an Oil Weapon?: Security Implications of Changes in the Structure of the International Oil Market, International Security, vol. 39, no. 3, pp. 152-189.

Koubi, V., Bernauer, T., Kalbhenn, A., Spilker, G., (2012), Climate Variability, Economic Growth, and Civil Conflict, Journal of Peace Research, vol. 49, no. 1, pp. 113-127.

Koubi, V., Spilker, G., Böhmelt, T., Bernauer, T., (2014), Do Natural Resources Matter for Interstate and Intrastate Armed Conflict?, Journal of Peace Research, vol, 51, no. 2, pp. 227-243.

Lujala, P., (2009), Deadly Combat Over Natural Resources Gems, Petroleum, Drugs, and the Severity of Armed Civil Conflict, Journal of Conflict Resolution, vol. 53, no. 1, pp. 50-71.

Månsson, A., (2014), Energy, Conflict and War: Towards a Conceptual Framework, Energy Research \& Social Science, vol. 4, pp. 106-116. Doi:10.1016/j.erss.2014.10.004.

Marshall, M., Jaggers, K., Gurr, T.R., (2010), Polity IV Project: Political Regime Characteristics and Transitions, 1800-2010. Available at: www.systemicpeace.org (accessed on March 2016).

Mikusheva, A., Poi, B.P., (2006), Tests and Confidence Sets with Correct Size when Instruments are Potentially Weak, Stata Journal, vol. 6, no. 3, pp. 335-347.

Mitchell, S.M., Thies, C.G., (2012), Resource Curse in Reverse: How Civil Wars Influence Natural Resource Production, International Interactions, vol. 38, no. 2, pp. 218-242.

Oneal, J.R., Russett, B., (1999), The Kantian Peace: The Pacific Benefits of Democracy, Interdependence, and International Organizations, 1885-1992, World Politics, vol. 52, no. 1, pp. 1-37.

Pevehouse, J.C., Nordstrom, T., Warnke, K., (2004), The COW-2 International Organizations Dataset Version 2.0, Conflict Management and Peace Science, vol. 21, no. 101-119. Available at: www.correlatesofwar.org (accessed on March 2016).

Polachek, S.W., Robst, J., Chang, Y.C., (1999), Liberalism and Interdependence: Extending the Trade-conflict Model, Journal of Peace Research, vol. 36, no. 4, pp. 405-422.

Powell, R., (2006), War as a Commitment Problem, International Organization, vol. 60, no. 01, pp. 169-203.

Ramsay, K.W., (2011), Revisiting the Resource Curse: Natural Disasters, the Price of Oil, and Democracy, International Organization, vol. 65, no. 03, pp. 507-529.

Reiter, D., (2003), Exploring the Bargaining Model of War, Perspectives on Politics, vol. 1, no. 01, pp. 27-43.

Reuveny, R., Kang, H., (1998), Bilateral Trade and Political Conflict/Cooperation: Do Goods Matter? Journal of Peace Research, vol. 35, no. 5, pp. 581-602.

Ross, M., (2006), A Closer Look at Oil, Diamonds, and Civil War, Annual Review of Political Science, vol. 9, no. 1, pp. 265-300.

Saidu, B., (2008), Regulating the Abuse of the Natural Monopoly of Pipelines in the Gas Industry vis-à-vis the Provision of Third Party Access, Journal of Structured Finance, vol. 13, no. 4, p. 105. 
Salehyan, I., (2008), No Shelter Here: Rebel Sanctuaries and International Conflict, The Journal of Politics, vol. 70, no. 1, pp. 54-76.

Smith, B., (forthcoming), Resource Wealth as Rent Leverage: Rethinking the Oil-Stability Nexus, Conflict Management and Peace Science. Doi: 10.1177/0738894215609000.

Sovacool, B.K., (2014), What Are We Doing Here? Analyzing Fifteen Years of Energy Scholarship and Proposing a Social Science Research Agenda, Energy Research \& Social Science, vol. 1, pp. 1-29.

Stinnett, D., Tir, J., Diehl, P., Schafer, P., Gochman, C., (2002), The Correlates of War (COW) Project Direct Contiguity Data, Version 3.0, Conflict Management and Peace Science, vol. 19, no. 2, pp. 59-67. Available at: www.correlatesofwar.org (accessed on March 2016).

The World Bank Indicators. Available at: http://beta.data.worldbank.org (accessed on March 2016).

Tsui, K.K., (2011), More Oil, Less Democracy: Evidence from Worldwide Crude Oil Discoveries, The Economic Journal, vol. 121, no. 551, 89-115.

Wagner, R.H., (2000), Bargaining and War, American Journal of Political Science, vol. 44, no. 3, pp. 469-484.

Yergin, D., (2006), Ensuring Energy Security, Foreign Affairs, vol. 85, no. 2, pp. 69-82.

Supplemental Material: The online version of this article (DOI: 10.1515/peps-2016-0001) offers supplementary material, available to authorized users. 